\title{
Investigation on fluid flow heat transfer and frictional properties of Al2O3 nanofluids used in shell and tube heat exchanger
}

sreejesh S R chandran

Karpagam Academy of Higher Education: Karpagam University

Debabrata Barik ( $\sim$ debabrata93@gmail.com )

Karpagam Academy of Higher Education: Karpagam University

ANSALAM RAJ T G

VALIYAKOONAMBAIKULATHAMMA College of Engineering Kerala India

Reby ROY

Research Dean, TKM College of Engineering, kollam, kerala, India

Original Article

Keywords: CFD, Flow and friction properties, Heat exchanger, Heat transfer rate, Nanofluid

Posted Date: November 4th, 2020

DOI: https://doi.org/10.21203/rs.3.rs-98296/v1

License: (c) (i) This work is licensed under a Creative Commons Attribution 4.0 International License.

Read Full License 


\title{
Investigation on fluid flow heat transfer and frictional properties of $\mathrm{Al}_{2} \mathrm{O}_{3}$ nanofluids used in shell and tube heat exchanger
}

\author{
${ }^{1}$ Sreejesh S R Chandran, ${ }^{* 1}$ Debabrata Barik, ${ }^{2}$ Ansalam Raj, ${ }^{3}$ K.E. Reby Roy \\ ${ }^{1}$ Department of Mechanical Engineering, Karpagam Academy of Higher Education, Coimbatore, \\ India-641021. \\ ${ }^{2}$ Principal, Valiya Koonambaikulathamma College of Engineering and Technology, Kollam, \\ Kerala, India. \\ ${ }^{3}$ Dean, Research and International Collaborations, TKM College of Engineering, Kollam, \\ Kerala, India. \\ ${ }^{* 1}$ Email: debabrata93@gmail.com
}

\begin{abstract}
Nanofluids are generally utilized in providing cooling, lubrication phenomenon, controlling the thermophysical properties of the working fluid. In this work, nanoparticles of $\mathrm{Al}_{2} \mathrm{O}_{3}$ are added to the base fluid which flows through the counter flow arrangement in a turbulent flow condition. The hot and cold fluids used are ethylbenzene and water respectively and have different velocities on both shell and tube side. This study emphasizes the analysis of flow properties, friction loss, and energy transfer in terms of heat using nanofluid in the heat exchanger. The heat transfer rate of present investigation with nanoparticle addition is $4.63 \%$ higher in comparision to Dittus Boelter correlation. Apart from this, the obtained friction factor is 0.0376 very much closer to Gnielinski and Blasius correlations. This investigation proved that appropriate nanoparticle additions and baffle inclinations have fabulous impact upon the performance of heat exchanger and its effectiveness.
\end{abstract}

Keywords: CFD; Flow and friction properties; Heat exchanger; Heat transfer rate; Nanofluid. 


\section{Nomenclature:}

\begin{tabular}{|ll|}
\hline$C p$ & Specific heat at constant pressure $(\mathrm{J} / \mathrm{kgK})$ \\
$K$ & Heat exchanger \\
$P$ & thermal conductivity $(\mathrm{W} / \mathrm{mK})$ \\
$T$ & Pressure $\left(\mathrm{N} / \mathrm{m}^{2}\right)$ \\
SBHX & Temperature $(\mathrm{K})$ \\
STHX & segmental baffle heat exchanger \\
$\mu$ & shell and tube heat exchanger \\
$\rho$ & Dynamic viscosity $(\mathrm{Kg} / \mathrm{m} . \mathrm{s})$ \\
$v$ & Density $\left(\mathrm{kg} / \mathrm{m}^{3}\right)$ \\
$\varphi$ & Kinematic viscosity $\left(\mathrm{m}^{2} / \mathrm{s}\right)$ \\
$f$ & Nanoparticle volume concentration \\
$D_{e}$ & Friction Factor \\
$V$ & Equivalent diameter for shell side $(\mathrm{m})$ \\
\hline & Velocity $(\mathrm{m} / \mathrm{s})$ \\
\hline
\end{tabular}

\section{Introduction}

The world of thermal engineering centred on the term Heat Exchanger (HX), which form the necessary for several industries where requisite for heat reduction economically. Hence the HX with low functional and management cost was designed with operating cooling fluids that extract the generated heat. The shell-tube style HX is recognized for its easiness in design, in general, it comprises up of following parts: Shell, Tube, baffles and the fluids. The shell forms the 
outermost portion by enclosing all other parts and liable for carrying the cooling fluids from entry to exit port over the tubes. The tube transmits the boiling fluid generated from the system by the cooling fluid where there is a transfer of heat among the fluids. The baffles are arrayed to alter the flow course of the cooling fluid in the HX. These varieties of HX have higher reliability in comparison with the other types as it can be operated at high pressure, possess higher surface area to volume ratio and effectiveness that can be easily enhanced by accumulating the tubes. In general, the heat transfer calculation by CFD is a complicated process as it requires a computer with more power and space. Hence the resolving of models is required.

There are numerous sorts of cooling fluids implemented in the HXs that involve varieties of water, oils and other organic compounds. Applications of heat exchangers are vast and require a thorough knowledge to cover each aspect. Among the applications, their main use is in the process industry, mechanical equipment, and home appliances. Heat exchangers are nowadays employed for heating district systems extensively Air conditioners, and refrigerators use heat exchangers to condense or evaporate the fluid. Moreover, it also has applications in milk processing to do pasteurization.

Nanofluids are solid-liquid compound materials comprising of solid nanoparticles or nanofibers with proportions usually from 1 to $100 \mathrm{~nm}$ dispersed in the fluid medium. This type of fluid is not just a plain liquid-solid combination while the utmost important condition of a nanofluid is an agglomerate-free stable suspension over an extended period without instigating any chemical alterations to its parent fluid. This can be well accomplished by reducing the density amid solids as well as liquids or by enhancing the viscosity of fluids, i.e., through the addition of nanometersized particles as well as by hindering particles from agglomeration, the settling of particles could be eluded (Sridhara \& Sutapathy, 2011). A lot of researches have been carried out on 
alumina-water and $\mathrm{TiO}_{2}$-water and the appropriate nanofluid for this study was chosen as $\mathrm{Al}_{2} \mathrm{O}_{3}$ - water nanofluid.

The influences of those cooling fluids on the performance of the heat exchanger were demonstrated through several pieces of research. Pak and Cho [1998] had stated when heat flux remains constant then $\mathrm{Nu}$ number of $\mathrm{Al}_{2} \mathrm{O}_{3}$ and $\mathrm{TiO}_{2}$ increases with a surge of Re number if the experiment is conducted on horizontal circular tube underflow of turbulent nature. They also conveyed that when there is $3 \%$ volume escalation in concentration, which is nearly a $12 \%$ decrease in the coefficient of convective heat transfer. In HX with two pipes by deploying Copper Oxide/Ethylene and Alumina/Ethylene Glycol, Zamzamian et al. [2011] resolved that with an upswing in temperature and volume concentration the heat transfer increase by $50 \%$ underflow of turbulent nature with low Nanofluid concentration.

Li and Xuan [2002] in their research on the comparison between the Darcy Weisbach friction factor and the heat transfer coefficient analytically on the $\mathrm{Cu}-\mathrm{H}_{2} \mathrm{O}$ nanofluids realized that there is a heat transfer enrichment under laminar/turbulent flow despite the value of $\mathrm{f}$ remains constant with increase in Nanofluids. The correlation stated that with an upsurge in volume concentration heat transfer rate increases by El Bécaye Maïga, et al. [2002] based on their study deploying $\mathrm{Al}_{2} \mathrm{O}_{3}$ nanofluid under the flow of turbulent nature. Wen and Ding [2004] indicated that there is progress in the rate of heat transfer with progress in Re number by consuming Alumina nanoparticles. The addition of nanoparticles increases the thermal behaviour of the nanofluid system was unravel by Chol and Eastman [1995] in their experiment. Hamilton and Crossover [1962] as well as Anoop, et al., [2009] established that larger the particles of nanofluid lesser would be the rate of heat transfer and added that shape and size of nanoparticle with its temperature upset the performance of heat transfer corresponding Nanofluid. 
The research conducted by Liu et al. [1988 ] revealed that there is a coincidence with the base fluid characteristics along with a negligible pressure drop. The behavior of heat transfer deploying $\mathrm{CuO} /$ ethylene glycol nanofluid under natural convection by Abu-Nada and Chamkha [2010] showed the escalation in the factor of friction and dynamic viscosity with the order of Alumina nanoparticle dispersion in water. Buongiorno [2006] illustrated the augmentation of heat transfer and turbulence when nanoparticles were added to the base fluids. Namburu et al. [2009] had led the experiment with several nanofluids added to the ethylene glycol water and analyzed the heat transfer performance numerically concluded that nanofluid had enhanced features than base fluid. There was an increase in $\mathrm{Re}$ and $\mathrm{Nu}$ numbers when the concentration of nanoparticle increases observed by Rott [1990]. The study conducted by Wakeham, et al. [1991] identified that the transport property depends on size, shape and volume fraction of nanoparticles. Heris et al. [2007] had numerically analyzed and exhibited substantial variation in the thermo-physical characteristics of base fluid when nanoparticles dispersed to it.

The dimpled helical tube was implemented by Suresh, et al. [2011) for experimentation on friction deploying $\mathrm{CuO}$-water nanofluid emulate the base fluid. Khaled and Vafai [2005]. The influence of nanoparticle characteristics on thermal conductivity is listed. By concentrating on the viscosity and conductivity (thermal) as vital properties, Masuda, et al. [1993] determined that the nanoparticles improve the thermal behavior. Nnanna [2007] highlighted at high temperature the $\mathrm{Nu}$ and Re number increases correspondingly with the heat transfer rate of $\mathrm{HX}$.

After the intensive literature survey, this work deals with the theoretical investigation on the forced convective $\mathrm{HX}$ and different flow behavior of fluids and Nanoparticles $\left(\mathrm{Al}_{2} \mathrm{O}_{3}\right)$ with homogeneous and counter flow arrangement under the flow of turbulent nature. The analysis is done for the different flow rates with and without nanofluid having $36 \%$ baffle cut arrangements 
without inclination. The study also establishes a substantial rise in the heat transfer properties when baffle with different spacing. The hot and cold fluid has considered as ethylbenzene and nanofluids have different velocities on both shell and tube optimum combination.

\section{Methodology}

\subsection{Shell tube type heat exchanger (STHX)}

Shell being the wall of STHX comprises of a tube arrangement which carries the hot fluid, and corresponding cooling fluid flows along the arrangement of the baffles in the shell side. The size and length of the shell depend largely on the number of tubes and its arrangement. Here, the geometry modeling was carried out using ANSYS Space Claim while the analysis was made using finite volume method as in Computational Fluid Dynamics (CFD) tool.

This study deals with the estimation of fluid flow and friction properties of a cold fluid added with nanoparticles of spherical dimensions in the heat exchanger. Here, ethyl-benzene is used as a hot fluid at a temperature of about $340 \mathrm{~K}$ whereas, the cold fluid is of two types, i.e., water and water- $\mathrm{Al}_{2} \mathrm{O}_{3}$ nanofluid fluid (WANF) at a temperature of $300 \mathrm{~K}$. The tube parameters such as diameter, pitch layout, and counts were determined for this HX.

It is noted from previous studies that pitch arrangement, number, orientation, and spacing of baffles along with their orientation can extraordinarily alter the overall efficacy of the heat exchanger. In this study, the triangular pitch has been selected for the tube bundles as it offers better results regarding enhanced surface area per unit length, i.e., maximum tube density. These tubes are generally built as bundles that can be easily dismounted from the tube arrangement (TFD-HE13 - STHX Design). The properties of $\mathrm{Al}_{2} \mathrm{O}_{3}$ nanoparticles are given in Table 1.

Table 1 Properties of $\mathrm{Al}_{2} \mathrm{O}_{3}$ nanoparticles. 


\begin{tabular}{ll}
\hline Properties & Values \\
\hline Density & $3.69 \mathrm{~g} / \mathrm{cm}^{3}$ \\
Flexural strength & $330 \mathrm{MPa}$ \\
Elastic modulus & $300 \mathrm{GPa}$ \\
Shear modulus & $124 \mathrm{GPa}$ \\
Bulk modulus & $165 \mathrm{GPa}$ \\
Poisson's ratio & 0.21 \\
Compressive strength & $2100 \mathrm{MPa}$ \\
Thermal conductivity & $18 \mathrm{~W} / \mathrm{mK}$ \\
Specific heat & $880 \mathrm{~J} / \mathrm{kgK}$ \\
\hline
\end{tabular}

The specifications of STHX has been taken from the studies of Irshad et al., (2017) and are given in Table 2.

Table 2 Geometric dimension of STHX.

\begin{tabular}{ll} 
Specification of STHX & Dimension \\
\hline The inner diameter of the shell & $90 \mathrm{~mm}$ \\
Length of the shell & $600 \mathrm{~mm}$ \\
The outer diameter of the tube & $20 \mathrm{~mm}$ \\
Number of tubes & 7 \\
Tube Pitch geometry & $30 \mathrm{~mm}$, triangular \\
Baffle cuts & $36 \%$ \\
Baffle spacing & $86 \mathrm{~mm}$ \\
Baffle thickness & $3 \mathrm{~mm}$ \\
Number of baffles & 6
\end{tabular}


The parameters of STHX were chosen according to Tubular Exchanger Manufacturers Association (TEMA) Standards (Bell, 2004) and were designed as in Figure 1 (a), and Figure 1 (b).

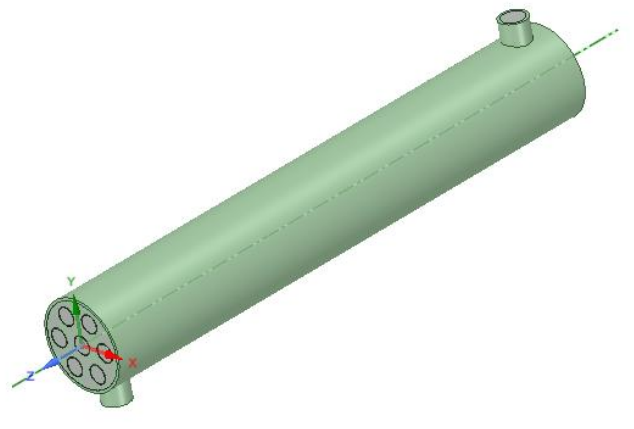

(a)

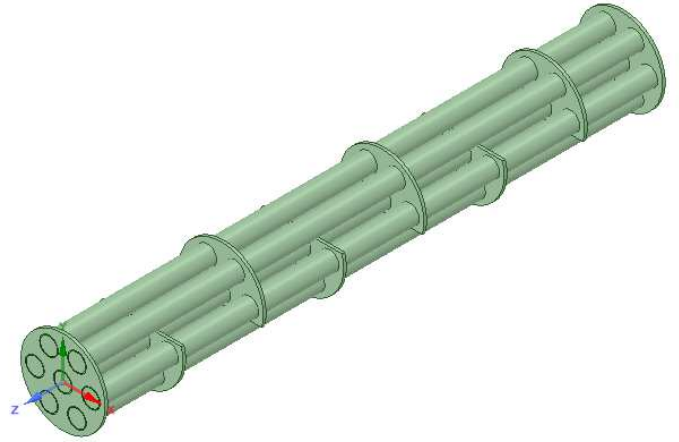

(b)

Figure 1 (a) STHX model (b) Tube bundle arrangement with baffles inside the shell.

The modeled STHX then meshed initially with a relatively coarser mesh which ended up in 58645 elements. This mesh comprised of mixed elements of both tetrahedral as well as hexahedral cells with triangular and quadrilateral faces at the boundaries. It was noted from the previous studies that, hexahedral cells are usually advised for a fine capturing of the profile. Hence, for this criteria, a fine mesh was made with maximum care at the wall regions and edges which are all the regions of high temperature and pressure gradients.

The contours of initially made coarse mesh were analyzed with that of the fine mesh and were observed that the latter mesh resolves in a better way over the regions of high pressure as well as temperature gradient than the former. The contours depicted a refinement in meshing particularly at the inlet and outlet regions which would help in the better acquisition of heat transfer and 
pressure drop. A completely grid independent model was obtained through interpretations made over the temperature and pressure gradients.

During fine meshing, the aspect ratio of the elements was maintained the same as that of the aspect ratio of coarse mesh as it possesses only a negligible effect on meshing. The resulting meshed model comprised of about 2184591 elements and 4473951 nodes. The different sections of the meshed model are shown in Figure 2.
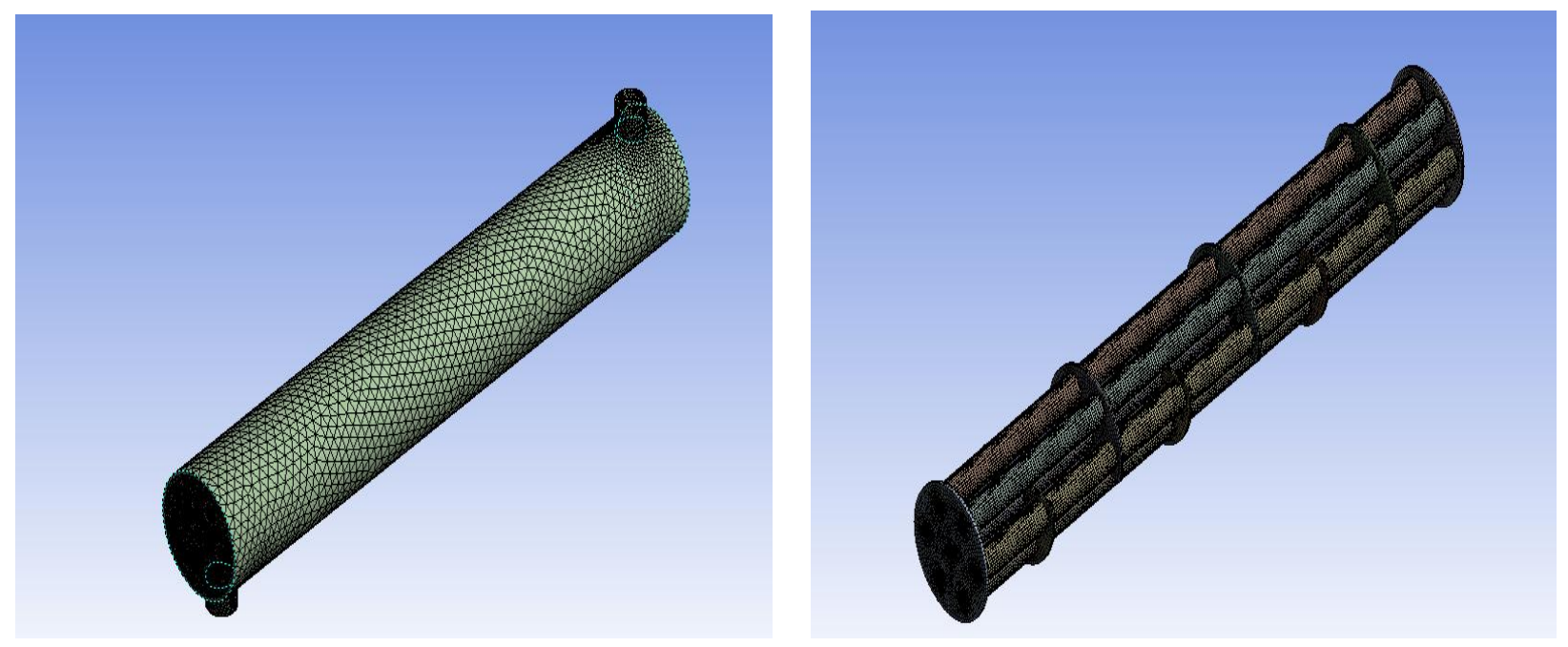


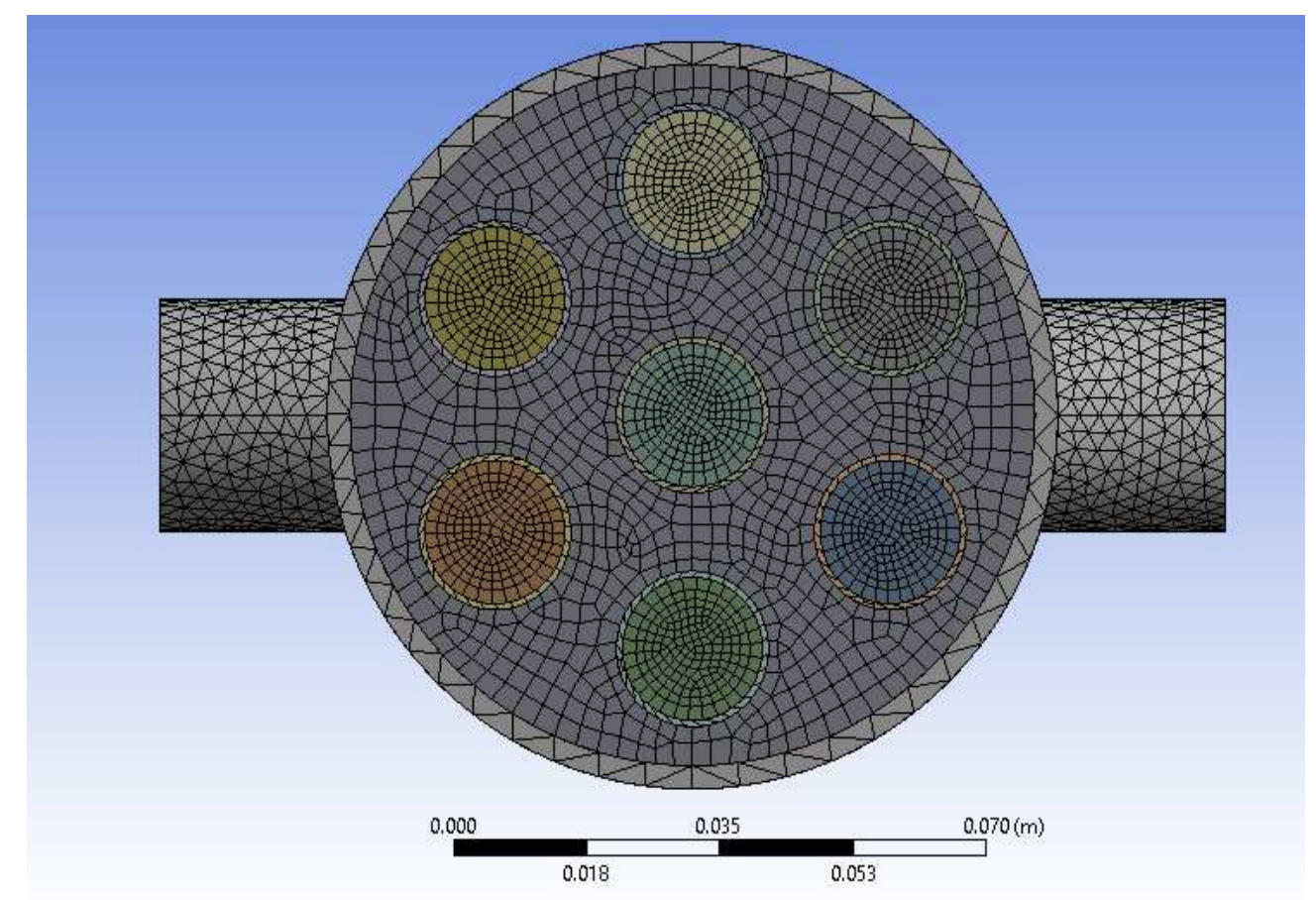

Figure 2 Meshed model.

The main concern of this investigation is to determine the fluid flow and friction properties along with the alterations in overall heat transfer due to addition of nanoparticles in the carrier fluid. The flow properties of fluid were referred to as,

$\vartheta$

- Dynamic Viscosity $\left(\mathrm{kg} \mathrm{m}^{-1} \mathrm{~s}^{-1}\right)$

K

- Thermal Conductivity $\left(\mathrm{W} \mathrm{m}^{-1} \mathrm{~K}^{-1}\right)$

$\rho$

- Density $\left(\mathrm{kg} \mathrm{m}^{-3}\right)$

$C_{p}$

- Specific Heat capacity $\left(\mathrm{J} \mathrm{kg}^{-1} \mathrm{~K}^{-1}\right)$

2.2 Governing equation of motion 
For a fluid flow, it should obey the three governing equations of motion viz. continuity, momentum, and energy (Ajithkumar et al., 2014). The three equations of motion are expressed as,

Continuity equation:

$$
\frac{\partial \rho}{\partial t}+\nabla \cdot(\rho V)=0
$$

Momentum equation:

$$
\rho \frac{D V}{D t}=\nabla \cdot \tau_{i j}-\nabla_{p}+\rho F
$$

Energy Equation:

$$
\rho \frac{D e}{D t}+p(\nabla \cdot V)=\frac{\partial Q}{\partial t}-\nabla \cdot q+\varphi
$$

where $\rho$ is the density of the fluid, $V$ is the velocity of fluid, $\tau_{i j}$ is the viscous stress tensor, $p$ is the pressure, $F$ is the body forces in the system, $e$ is the internal energy of the fluid, $Q$ is the heat transfer, $t$ is the time, $\varphi$ is the dissipation and $\nabla . q$ is the heat lost by conduction.

\subsection{Data analysis}

The flow and friction properties of nanofluids, are determined from the base values of particles which are used in the heat exchanger. These are determined using the below-mentioned formulae. The density of nanofluid resulting through the mixing of the base fluid; which means water and alumina nanoparticles is obtained through,

$$
\rho_{n f}=\left[(1-\varphi) \rho_{f}+\varphi \rho_{p}\right]
$$


In the same manner, the specific heat capacity of the nanofluid is given as,

$$
\left(\rho C_{p}\right)_{n f}=(1-\varphi)\left(\rho C_{p}\right)_{f}+\varphi\left(\rho C_{p}\right)_{p}
$$

The effective thermal conductivity of resultant nanofluid comprising of the solid-liquid mixture can be expressed as (Xue, 2003),

$$
K_{n f}=K_{f} \frac{\left(K+2 K_{f}-2 \varphi\left(K_{f}-K\right)\right)}{\left(K+2 K_{f}+\varphi\left(K_{f}-K\right)\right)}
$$

Similarly, the dynamic viscosity of nanofluids with very low volume concentrations of nanoparticles is given by Einstein model of 1906 as (Bashirnezhad et al., 2016),

$$
\frac{\mu_{n f}}{\mu_{f}}=[1+2.5 \varphi]
$$

where, the subscripts $f, p$ and $n f$ refers to the base fluid, nanoparticles and the nanofluids respectively. The next parameter that is to be determined is the overall heat transfer rate of the system which is given as,

The overall heat transfer rate, $Q=\dot{m} C_{p_{n f}}\left(T_{\text {out }}-T_{\text {in }}\right)$

Here, $\dot{m}$ is the mass flow rate of the nanofluid system, $T_{\text {out }}$ and $T_{\text {in }}$ are the outlet and inlet temperatures of the nanofluids. In case of the friction factor of the system, it is obtained through, 198 Barzegar and Fallahiyekt (2018). The nanofluid correlation for friction factor is given by $f_{n f}=0.961 R e^{-0.375} \varphi^{0.052}$, 
where $\operatorname{Re}$ is the Reynolds number and $\varnothing$ is the particle concentration. In the present work, turbulent flow is considered. It is added that Reynolds' number also determines the nature of the flow and is given as,

$\boldsymbol{R e}=\frac{V D_{e}}{\vartheta}$

The obtained results regarding heat transfer rate and friction factor were then correlated with various models of heat transfer correlations by Dittus -Boelter (Eqn.11, 12), Gnielinski (Eqn.13) and Blasius (Eqn.14) presented as in the below equations.

$\frac{h_{i} D_{i}}{k}=0.023\left(\frac{G_{i} D_{i}}{\mu}\right)^{0.8}\left(\frac{C_{p} \mu}{k}\right)^{0.3}$

$Q=h A \Delta T$

$f=(0.79 \ln (R e)-1.64)^{-2}$,

$f=\frac{0.316}{R e^{0.25}}$

\subsection{Grid independence test}

Grid independence study is considered as an important procedure in all CFD analysis. The reason is that the solution which is delivered by the CFD software should be independent of the grid size. This study helps to find out an optimum point where a suitable accurate solution for the problem with reduced computational resources. With the help of the obtained optimum mesh, the accuracy of the result would be good enough to get all relevant flow features, its gradient and so on. Grid independent study is conducted for four grid quantities such as 0.5 million, 1 million, 1.5 million, 2 million, 2.5 million, 3 million for the turbulent flow regime. The friction factor $\mathrm{f}$ is 
taken as one of the parameters to check the grid in dependency. From the study the 2.1 million grid quantity is selected for further computations since the parameters with the higher mesh density 60 (width) $\times 70$ (depth) $\times 600$ (length) for the fluid domain do not have appreciable variation as shown in the Figure 3. Hence, a comparatively less mesh density is selected for the solid domain.

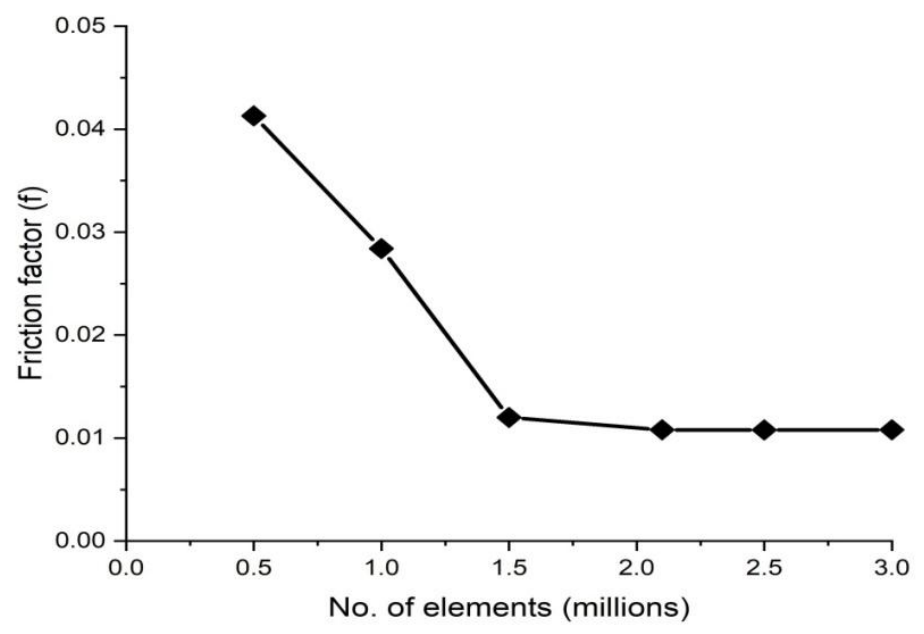

Figure 3 Grid independence study for turbulent regime.

\section{Results and discussion}

This section deals with the experimental calculation of flow and friction properties of the nanofluid within the shell tube type heat exchanger. The properties of base fluid and nanoparticle are tabulated in Table 3.

Table 3 Properties of base fluid and nanoparticles.

Properties

Density
Base fluid (Water)

$998.2 \mathrm{~kg} / \mathrm{m}^{3}$
Nanoparticle $\left(\mathrm{Al}_{\mathbf{2}} \mathrm{O}_{3}\right)$

$3690 \mathrm{~kg} / \mathrm{m}^{3}$ 


\begin{tabular}{lll}
\hline Thermal conductivity & $0.608 \mathrm{~W} / \mathrm{m} \mathrm{K}$ & $18 \mathrm{~W} / \mathrm{m} \mathrm{K}$ \\
Dynamic viscosity & 0.001002 & - \\
Specific heat capacity & $4182 \mathrm{~J} / \mathrm{kg} \mathrm{K}$ & $880 \mathrm{~J} / \mathrm{kg} \mathrm{K}$ \\
\hline
\end{tabular}

For a Counterflow type STHX and the observed value for the base fluid and nanoparticle, the flow and friction properties are calculated in the case of $99 \%$ of water and $1 \%$ of $\mathrm{Al}_{2} \mathrm{O}_{3}$ nanoparticles as,

From Eqn. (4), the density of the nanofluid $\rho_{n f}$ can be calculated as,

$$
\left(\rho_{n f}\right)=\left[(1-\varphi) \rho_{f}+\varphi \rho_{p}\right]
$$

Here, $\rho_{f}=998.2 \mathrm{~kg} / \mathrm{m}^{3}, \rho_{p}=3690 \mathrm{~kg} / \mathrm{m}^{3}$ and $\varphi=0.01$

Therefore,

$$
\begin{aligned}
& \left(\rho_{n f}\right)=[(1-0.01) 998.2+(0.01) 3690] \\
& \left(\rho_{n f}\right)=1025.118 \mathrm{~kg} / \mathrm{m}^{3}
\end{aligned}
$$

Similarly, from Eqn. (5), the dynamic viscosity $\left(\rho C_{p}\right)_{n f}$ can be calculated as,

$$
\left(\rho C_{p}\right)_{n f}=(1-\varphi)\left(\rho C_{p}\right)_{f}+\varphi\left(\rho C_{p}\right)_{p}
$$

where, $\left(\rho C_{p}\right)_{f}=4182 \mathrm{~J} / \mathrm{kg} \mathrm{K} ;\left(\rho C_{p}\right)_{p}=880 \mathrm{~J} / \mathrm{kg} \mathrm{K}$ and $\varphi=0.01$.

Hence,

$$
\left(\rho C_{p}\right)_{n f}=[(1-0.01) 4182+(0.01)(880)]
$$




$$
=4148.98 \mathrm{~J} / \mathrm{kg} \mathrm{K}
$$

For the thermal conductivity $\left(K_{n f}\right)$, the Eqn. (6) can be expressed as,

$$
K_{n f}=K_{f} \frac{\left(K+2 K_{f}-2 \varphi\left(K_{f}-K\right)\right)}{\left(K+2 K_{f}+\varphi\left(K_{f}-K\right)\right)}
$$

where, $K_{f}=0.608 \mathrm{~W} / \mathrm{m} \mathrm{K} ; K=18 \mathrm{~W} / \mathrm{m} \mathrm{K}$ and $\varphi=0.01$. Hence, the thermal conductivity of the nanofluid can be calculated as,

$$
\begin{aligned}
K_{n f} & =0.608 \frac{(18+2 * 0.608-2 * 0.01(0.608-18))}{(18+2 * 0.608+0.01(0.608-18))} \\
& =0.6131 \mathrm{~W} / \mathrm{m} \mathrm{K}
\end{aligned}
$$

In case of dynamic viscosity of the nanofluid $\mu_{n f}$, Eqn. (7), can be used as,

$$
\frac{\mu_{n f}}{\mu_{f}}=[1+2.5 \varphi]
$$

where, $\mu_{f}=0.001002 \mathrm{~kg} / \mathrm{m} \mathrm{s}$ and $\varphi=0.01$. Hence, the dynamic viscosity of the nanofluids can be calculated as,

$$
\begin{aligned}
& \mu_{n f}=0.001002[1+2.5 * 0.01] \\
& \quad=0.0010275 \mathrm{~kg} / \mathrm{ms}
\end{aligned}
$$

To determine the other parameters like friction factor and heat transfer rate, the outlet temperature of the nanofluid was needed. To determine these temperatures, the analysis was 
carried out in ANSYS - Fluent and the temperature contours achieved through the test were expressed below.

During CFD analysis, a realizable $\mathrm{k}-\varepsilon$ turbulence has been utilized. The selection of the turbulence model is generally very critical in any CFD simulation, and this sort of convergence was selected for this study as the obtained Mach number was below the selected range of 0.3. The boundary walls are assigned individually with preferable boundary conditions. Similarly, the conditions of no-slip were assumed while all the boundary walls except tube walls are set to zero heat flux.

In addition to the above-mentioned assumptions, the convergence criterion was assumed to the $10^{-3}$ range, and thus the boundary conditions assigned at the initial stage was tabulated in Table 4.

Table 4 Assigned boundary condition.

\begin{tabular}{llllll}
\hline Position & $\begin{array}{l}\text { Boundary } \\
\text { condition } \\
\text { type }\end{array}$ & $\begin{array}{l}\text { Velocity, } \\
\mathrm{m} / \mathrm{s}\end{array}$ & $\begin{array}{l}\text { Turbulent } \\
\text { kinetic energy, } \\
\mathrm{m}^{2} / \mathrm{s}^{2}\end{array}$ & $\begin{array}{l}\text { Turbulent } \\
\text { dissipation } \\
\text { rate, } \mathrm{m}^{2} / \mathrm{s}^{3}\end{array}$ & Temperature, k \\
\hline $\begin{array}{l}\text { Hot Fluid } \\
\text { inlet }\end{array}$ & Velocity Inlet & 0.7 & 0.01 & 0.1 & 340 \\
$\begin{array}{l}\text { Cold Fluid } \\
\text { inlet }\end{array}$ & Velocity Inlet & 0.1 & 0.01 & 0.1 & 300 \\
\hline
\end{tabular}

The temperature contours obtained through the flow of base fluid alone and nanofluid with $1 \%$ $\mathrm{Al}_{2} \mathrm{O}_{3}$ over $\mathrm{STHX}$ can be expressed in Figure 4 and Figure 5 respectively. These temperature contours show the relevance of using nanoparticle along with the base fluid and how fast it enhances the heat transfer when compared with base fluid water. Figure 4 (a) and Figure 4 (b) 
denote the temperature contours of base fluid and it is quite clear that the phenomenon of heat transfer is poor in base fluids, but it is enhanced when nanoparticles are added. In Figure 5 (a) and Figure 5 (b), the heat transfer rates are quite appreciable and red colour shows the points for higher heat transfer and gradually it would become yellow, green and blue when heat transfer rate decreases. The blue colour shows the area of least heat transfer. The reason for this is, while analyzing the phenomenon, at points where reverse flow happens, the temperature need not be uniform. It is added that at points where maximum heat transfer is obtained, shell side and tube side fluid colour changes at a faster rate. This change is not uniform at different points measured from inlet to outlet. The heat transfer phenomenon is not uniform in all tubes, provided it would be tackled after a long time when required heat transfer is attained. The reason for the colour difference (blue colour in Figure 5 (b)) is due to reverse flow and gradually the temperature would be same as in other tubes after a certain period of time. Reverse flow phenomenon is quite common in the analysis, thereby reduces the heat transfer rates and it increased the computation time also. The blue colour has been taken as a proof of reverse flow in the analysis.

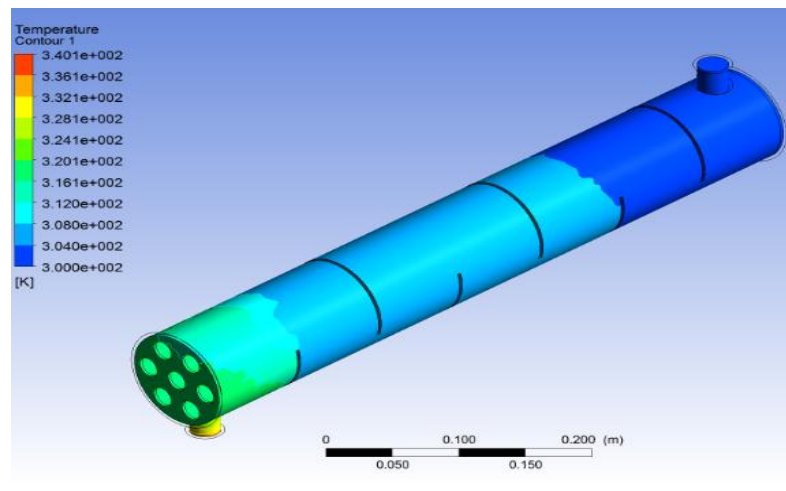

(a)

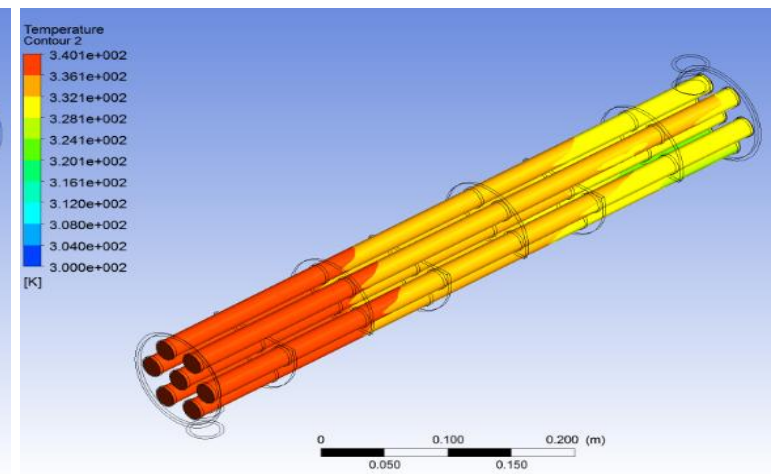

(b)

Figure 4 Temperature contours of (a) Cold fluid (b) Hot fluid through the tubes. 
The Figure 4 and Figure 5 represent the temperature contours of plain base fluid and nanofluid over the STHX through the analysis. From the above-obtained contours, the temperatures obtained were,

$$
\begin{aligned}
& \mathrm{T}_{\text {out }}(\text { base fluid })=322 \mathrm{~K} \\
& \mathrm{~T}_{\text {out }}(\text { Nanofluid })=330 \mathrm{~K}
\end{aligned}
$$

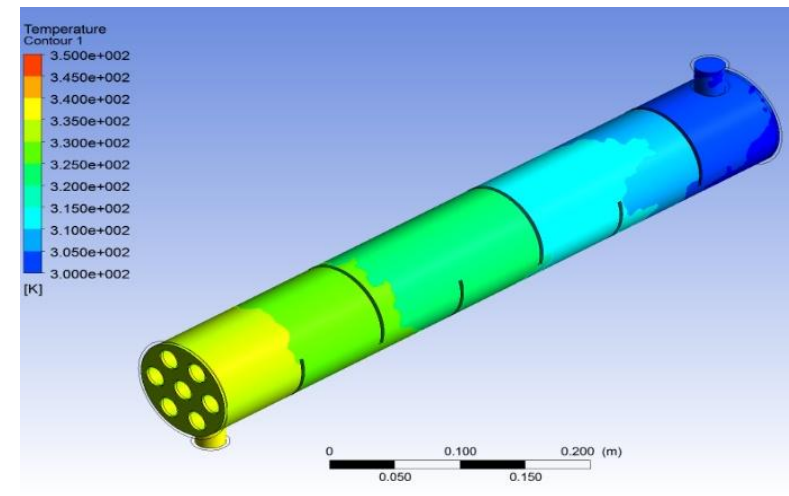

(a)

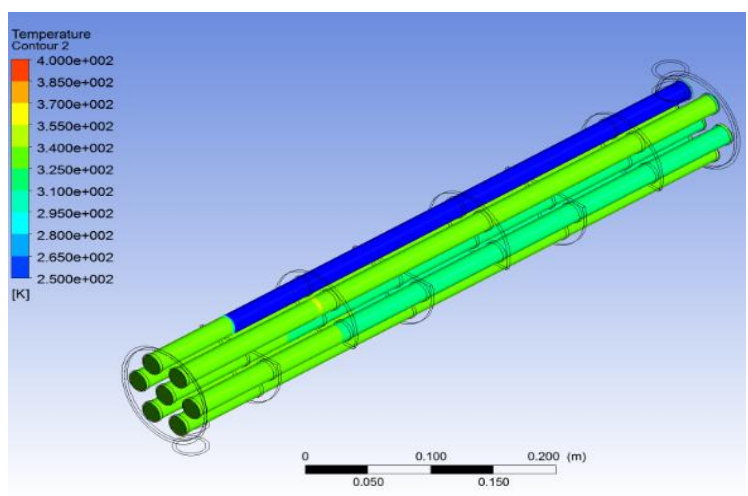

(b)

Figure 5 Temperature contours of (a) Nanofluid with $1 \% \mathrm{Al}_{2} \mathrm{O}_{3}$ (b) Hot fluid through the tubes.

Thus, from this temperature, the heat transfer rate $Q$ can be calculated from the Eq. (8) as,

$$
Q=\dot{m} C_{p_{n f}}\left(T_{\text {out }}-T_{\text {in }}\right)
$$

Here, mass flow rate $\dot{m}$ has to be calculated for which the Reynolds' number Re and $\mathrm{S}_{\mathrm{s}}$ has to be calculated through Eq. (10) as,

$$
R e=\frac{V D_{e}}{\vartheta_{n f}}
$$

Here, $D_{e}=\frac{4\left(0.5 * P_{T} * 0.86 * P_{T}-0.5 * \pi * d_{0}{ }^{2}\right)}{0.5 * \pi * d_{0}}$ 
Where, $P_{T}=$ Tube Pitch $=0.03 \mathrm{~m}, d_{0}=$ tube outside diameter $=0.02 \mathrm{~m}$

Therefore, $\quad D_{e}=\frac{4\left(0.5 * 0.03 * 0.86 * 0.03-0.5 * \pi * 0.02^{2}\right)}{0.5 * \pi * 0.02}$

$$
=0.03 \mathrm{~m}
$$

And,

$$
\begin{aligned}
\vartheta_{n f} & =\frac{\mu_{n f}}{\rho_{n f}} \\
& =\frac{0.0010275}{1025.118} \\
& =1.00232 \mathrm{e}^{-6} \mathrm{~m}^{2} / \mathrm{s}
\end{aligned}
$$

Therefore,

$$
\begin{aligned}
& R e=\frac{0.1 * 0.03}{1.00232 e^{-6}} \\
& R e=2993
\end{aligned}
$$

To get $S s$,

$$
S_{S}=\frac{D_{S} P_{D} L_{B}}{P_{T}}
$$

Where, $D_{s}=$ Shell internal diameter $=0.09 \mathrm{~m}$

$$
\begin{aligned}
& P_{D}=\text { tube spacing }=0.0015 \mathrm{~m} \\
& L_{B}=\text { baffle spacing length }=0.086 \mathrm{~m}
\end{aligned}
$$

Hence, 


$$
\begin{gathered}
S_{S}=\frac{0.09 * 0.0015 * 0.086}{0.03} \\
S_{S}=0.000387 \mathrm{~m}^{2}
\end{gathered}
$$

Therefore, the mass flow rate $\dot{m}$ can be achieved as,

$$
\begin{gathered}
\dot{m}=\frac{R e * \mu_{n f} * S_{s}}{D_{e}} \\
\dot{m}=\frac{2993 * 0.0010275 * 0.000387}{0.03} \\
\dot{m}=0.04 \mathrm{~kg} / \mathrm{s}
\end{gathered}
$$

Hence, from Eq. (8), the heat transfer rate Q can be calculated as,

$$
\begin{gathered}
Q=0.04 * 4148.98 *(330-300) \\
Q=4978.776 \mathrm{~W}
\end{gathered}
$$

Thus, the friction factor for the nanofluid can be expressed through the Eq. (9) as,

$$
\begin{gathered}
f_{n f}=0.961 * 2993^{-0.375} * 0.01^{0.052} \\
f_{n f}=0.0376
\end{gathered}
$$

\subsection{Validation and correlation}


The obtained results for the assumed inlet condition of $300 \mathrm{~K}$ with $0^{\circ}$ baffle inclination angle were validated with the data available through results from various literature studies. The results were tabulated in Table 5

Table 5 Results obtained.

\begin{tabular}{|l|l|l|l|}
\hline Reference & Mass Flow rate $(\mathrm{kg} / \mathrm{s})$ & Heat transfer rate, W & Temperature outlet, K \\
\hline Irshad, et.al, 2017 & 0.5 & 66848 & 339.2 \\
\hline Present study & 0.5 & 62234.7 & 330 \\
\hline
\end{tabular}

From the table, it is found that, for $0^{\circ}$ baffle inclination and a constant mass flow rate of $0.5 \mathrm{~kg} / \mathrm{s}$, the obtained heat transfer rate was $66848 \mathrm{~W}$ while in case of this proposed technique, the obtained heat transfer rate was $62234.7 \mathrm{~W}$ for $0.5 \mathrm{~kg} / \mathrm{s}$. On comparing the results, the deviation between the heat transfer rates was found to be $6.9 \%$ while that of outlet temperature was found to be $2.71 \%$. Here, relative deviation for outlet temperature is suitable to use in the present work because the outlet temperature difference is less than $10^{\circ} \mathrm{C}$. For general heat exchanger calculations, a temperature difference up to $10^{\circ} \mathrm{C}$ can be taken under the acceptable limit. This validates that the obtained results are almost in parallel to the ideal results that are to be obtained through a shell and tube type heat exchanger with $0^{\circ}$ inclined baffles.

The correlations have been checked with Dittus - Boelter relation and are tabulated in Table 6.

Table 6 correlations of heat transfer rate.

\begin{tabular}{|l|l|c|}
\hline Heat transfer rate (obtained) & Heat transfer rate (Dittus - Boelter relation) & Error, \% \\
\hline
\end{tabular}




\begin{tabular}{|l|l|l|}
\hline $4978.78 \mathrm{~W}$ & $5220.43 \mathrm{~W}$ & $4.63 \%$ \\
\hline
\end{tabular}

From the above results, it can be noted that the variation between the implemented technique (Kern's equation) and Dittus-Boelter relation was only $4.63 \%$, which shows that, the obtained results obey the correlations of Dittus-Boelter relation and the error is in the acceptable range.

In case of friction factor through the implemented technique along with Gnielinski correlation and Blasius correlation, the values are tabulated in Table 7.

Table 7 Gnielinski correlation and obtained rerults comparision.

\begin{tabular}{|c|c|c|c|c|}
\hline $\begin{array}{c}\text { Friction } \\
\text { Factor }\end{array}$ & $\begin{array}{c}\text { Obtained } \\
\text { result }\end{array}$ & $\begin{array}{c}\text { Gnielinski } \\
\text { Correlation }\end{array}$ & $\begin{array}{c}\text { Obtained } \\
\text { result }\end{array}$ & $\begin{array}{c}\text { Blasius } \\
\text { Correlation }\end{array}$ \\
\cline { 2 - 6 } & 0.0376 & 0.0456 & 0.0376 & 0.0427 \\
\hline \% Variation & \multicolumn{2}{|c|}{$17.54 \%$} & \multicolumn{2}{|c|}{$11.94 \%$} \\
\hline
\end{tabular}

The results obtained depicts that, there exists a substantial variation in the friction factor correlation in case of both Gnielinski as well as Blasius correlations.

\section{Conclusion}

Investigation and numerical analysis have been carried out to determine the flow and friction 356 properties of nanofluids in a shell and tube heat exchanger using $\mathrm{Al}_{2} \mathrm{O}_{3}$ nanofluid. It was found from the experiments that, water along with $\mathrm{Al}_{2} \mathrm{O}_{3}$ nanofluid of $1 \%$ volume concentration has better heat transfer rate compared with normal base fluid alone, i.e. only water. All the analysis have proved that there occurs a substantial increase in the heat transfer rates followed by an earlier convergence history. It is clear from the experiment that, the addition of nanoparticles produced a positive effect on the flow as well as friction properties of cold fluids. The 
quantitative value of friction factor for the present investigation was observed to be 0.0376 which is very much nearer to results obtained from Gnielinski correlation and Blasius correlation. It can be further noted that the heat transfer rate can be increased if baffle inclinations are provided with the shell.

\section{Declaration}

I do hereby declare that the informations furnished in the manuscript is unique and genuine in nature.

\section{REFERENCES}

[1]. Abu-Nada, E., \& Chamkha, A. J. (2010). Effect of nanofluid variable properties on natural convection in enclosures filled with a CuO-EG-water nanofluid. International Journal of Thermal Sciences, 49(12), 2339-2352.

[2]. Ajithkumar, M. S., Ganesha, T., \& Math, M. C. (2014). CFD analysis to study the effects of inclined baffles on fluid flow in a Shell and tube Heat Exchanger. International Journal of Research in Advent Technology, 2(7), 164-175.

[3]. Anoop, K. B., Sundararajan, T., \& Das, S. K. (2009). Effect of particle size on the convective heat transfer in nanofluid in the developing region. International Journal of Heat and Mass Transfer, 52(9-10), 2189-2195.

[4]. Bashirnezhad, K., Bazri, S., Safaei, M. R., Goodarzi, M., Dahari, M., Mahian, O., \& Wongwises, S. (2016). Viscosity of nanofluids: A review of recent experimental studies. International Communications in Heat and Mass Transfer, 73, 114-123.

[5]. Kumar, N Sonawane, S. S Sonawane (2018). Experimental study of thermal conductivity, heat transfer and friction factor of $\mathrm{Al}_{2} \mathrm{O}_{3}$ based nanofluid. International Communications in Heat and Mass Transfer, 90, 1-10. 385. 
[6]. Buongiorno, J. (2006). Convective transport in nanofluids. Journal of heat transfer, 128(3), 240-250.

[7]. Chol, S. U. S., Estman, J. A. (1995). Enhancing thermal conductivity of fluids with 388 nanoparticles. ASME-Publications-Fed, 231, 99-106.

[8]. El Bécaye Maïga, S., Tam Nguyen, C., Galanis, N., Roy, G., Maré, T., \& Coqueux, M. (2006). Heat transfer enhancement in turbulent tube flow using $\mathrm{Al}_{2} \mathrm{O}_{3}$ nanoparticle suspension. International Journal of Numerical Methods for Heat \& Fluid Flow, 16(3), 392 275-292.

[9]. Farajollahi, B., Etemad, S. G., \& Hojjat, M. (2010). Heat transfer of nanofluids in a shell and tube heat exchanger. International Journal of Heat and Mass Transfer, 53(1-3), 12-17.

[10]. Bahiraei, M., Hangi, M., Saeedan M. (2015). A novel application for energy efficiency improvement using nanofluid in shell and tube heat exchanger equipped with helical baffles. Energy, 93, 2229-2240.

[11]. Heris, S. Z., Esfahany, M. N., and Etemad, G. (2007). Numerical investigation of nanofluid laminar convective heat transfer through a circular tube. Numerical Heat Transfer, Part A: Applications, 52(11), 1043-1058.

[12]. Irshad, M., Kaushar, M., \& Rajmohan, G. (2017). Design and CFD analysis of Shell and Tube Heat Exchanger. International Journal of Engineering Science and Computing, 7(4), 6453-6457.

[13]. Khaled, A. R., \& Vafai, K. (2005). Heat transfer enhancement through control of thermal dispersion effects. International Journal of Heat and Mass Transfer, 48(11), 2172-2185.

[14]. Koo and Kleinstreuer, C. (2005). Laminar nanofluid flow in microheat sinks. International Journal of Heat and Mass Transfer, 48(13), 2652-2661. 
[15]. Li, Q., Xuan, Y. (2002). Convective heat transfer and flow characteristics of Cu-water nanofluid. Science in China Series E: Technolgical Science, 45(4), 408-416.

[16]. Liu, K. V., Choi, U. S., Kasza, K. E. (1988). Measurements of pressure drop and heat transfer in turbulent pipe flows of particulate slurries. NASA STI/Recon Technical Report N, 89.

[17]. Qi, C., Luo, T., Liu, M., Fan, F., Yan Y. (2019). Experimental study on the flow and heat transfer characteristics of nanofluids in double-tube heat exchangers based on thermal efficiency assessment. Energy Conversion and Management, 197, 111877.

[18]. Namburu, P. K., Das, D. K., Tanguturi, K. M., \& Vajjha, R. S. (2009). Numerical study of turbulent flow and heat transfer characteristics of nanofluids considering variable properties. International Journal of Thermal Sciences, 48(2), 290-302.

[19]. Nnanna, A. G. (2007). Experimental model of temperature-driven nanofluid. Journal of Heat Transfer, 129(6), 697-704.

[20]. Pak, B. C., \& Cho, Y. I. (1998). Hydrodynamic and heat transfer study of dispersed fluids with submicron metallic oxide particles. Experimental Heat Transfer an International Journal, 11(2), 151-170.

[21]. Ardekani, A.M., Kalantar, V., Heyhat, M.M. (2019). Experimental study on heat transfer enhancement of nanofluid flow through helical tubes. Advanced Powder Technology, 30, $1815-1822$.

[22]. Sridhara, V., Satapathy, L. N. (2011). $\mathrm{Al}_{2} \mathrm{O}_{3}$-based nanofluids: a review. Nanoscale research letters, 6(1), 456.

[23]. Suresh, S., Chandrasekar, M., Sekhar, S. C. (2011). Experimental studies on heat transfer and friction factor characteristics of $\mathrm{CuO} /$ water nanofluid under turbulent flow in helically dimpled tube. Experimental Thermal and Fluid Science, 35(3), 542-549. 
[24]. Subramani, K., Logesh, K., Kolappan, S., Karthik, S. (2018): Experimental investigation on heat transfer characteristics of heat exchanger with bubble fin assistance, International Journal of Ambient Energy, DOI:10.1080/01430750.2018.1472654.

[25]. Wen, D., and Ding, Y. (2004). Experimental investigation into convective heat transfer of nanofluids at the entrance region under laminar flow conditions. International journal of heat and mass transfer, 47(24), 5181-5188.

[26]. Xue, Q. Z. (2003). Model for effective thermal conductivity of nanofluids. Physics letters A, 307(5-6), 313-317.

[27]. Zamzamian, A., Oskouie, S. N., Doosthoseini, A., Joneidi, A., and Pazouki, M. (2011). Experimental investigation of forced convective heat transfer coefficient in nanofluids of $\mathrm{Al}_{2} \mathrm{O} 3 / \mathrm{EG}$ and $\mathrm{CuO} / \mathrm{EG}$ in a double pipe and plate heat exchangers under turbulent flow. Experimental Thermal and Fluid Science, 35(3), 495-502.

[28]. Barzegar, M.H., Fallahiyekt M. (2018). Increasing the thermal efficiency of double tube Heat Exchangers by using nano hybrid. Emerging science Journal, 2, 1-10. 
[29]. Beckman, L. V., Law, V. J., Bailey, R. V., \& Von Rosenberg, D. U. (1990). Axial dispersion for turbulent flow with a large radial heat flux. AIChE journal, 36(4), 598-604.

[30]. Bell, K. J. (2004, January). Heat exchanger design for the process industries. In ASME 2004 Heat Transfer/Fluids Engineering Summer Conference (pp. 921-959). American Society of Mechanical Engineers.

[31]. Buongiorno, J. (2006). Convective transport in nanofluids. Journal of heat transfer, 128(3), 240-250.

[32]. Chol, S. U. S., \& Estman, J. A. (1995). Enhancing thermal conductivity of fluids with nanoparticles. ASME-Publications-Fed, 231, 99-106.

[33]. El Bécaye Maïga, S., Tam Nguyen, C., Galanis, N., Roy, G., Maré, T., \& Coqueux, M. (2006). Heat transfer enhancement in turbulent tube flow using Al2O3 nanoparticle suspension. International Journal of Numerical Methods for Heat \& Fluid Flow, 16(3), 275292.

[34]. Farajollahi, B., Etemad, S. G., \& Hojjat, M. (2010). Heat transfer of nanofluids in a shell and tube heat exchanger. International Journal of Heat and Mass Transfer, 53(1-3), 12-17.

[35]. Hamilton, R. L., \& Crosser, O. K. (1962). Thermal conductivity of heterogeneous twocomponent systems. Industrial \& Engineering chemistry fundamentals, 1(3), 187-191. 
[36]. Heris, S. Z., Esfahany, M. N., \& Etemad, G. (2007). Numerical investigation of nanofluid laminar convective heat transfer through a circular tube. Numerical Heat Transfer, Part A: Applications, 52(11), 1043-1058.

[37]. Irshad, M., Kaushar, M., \& Rajmohan, G. (2017). Design and CFD Analysis of Shell and Tube Heat Exchanger. International Journal of Engineering Science and Computing, 7.

[38]. Khaled, A. R., \& Vafai, K. (2005). Heat transfer enhancement through control of thermal dispersion effects. International Journal of Heat and Mass Transfer, 48(11), 2172-2185.

[39]. Koo, J., \& Kleinstreuer, C. (2005). Laminar nanofluid flow in microheat-sinks. International Journal of Heat and Mass Transfer, 48(13), 2652-2661.

[40]. Li, Q., \& Xuan, Y. (2002). Convective heat transfer and flow characteristics of Cu-water nanofluid. Science in China Series E: Technolgical Science, 45(4), 408-416.

[41]. Liu, K. V., Choi, U. S., \& Kasza, K. E. (1988). Measurements of pressure drop and heat transfer in turbulent pipe flows of particulate slurries. NASA STI/Recon Technical Report N, 89.

[42]. Masuda, H., Ebata, A., \& Teramae, K. (1993). Alteration of thermal conductivity and viscosity of liquid by dispersing ultra-fine particles. Dispersion of $\mathrm{Al} 2 \mathrm{O} 3, \mathrm{SiO} 2$ and $\mathrm{TiO} 2$ ultra-fine particles.

[43]. Namburu, P. K., Das, D. K., Tanguturi, K. M., \& Vajjha, R. S. (2009). Numerical study of turbulent flow and heat transfer characteristics of nanofluids considering variable properties. International Journal of Thermal Sciences, 48(2), 290-302.

[44]. Nnanna, A. G. (2007). Experimental model of temperature-driven nanofluid. Journal of Heat Transfer, 129(6), 697-704. 
[45]. Pak, B. C., \& Cho, Y. I. (1998). Hydrodynamic and heat transfer study of dispersed fluids with submicron metallic oxide particles. Experimental Heat Transfer an International Journal, 11(2), 151-170.

[46]. Rott, N. (1990). Note on the history of the Reynolds number. Annual review of fluid mechanics, 22(1), 1-12.

[47]. Sridhara, V., \& Satapathy, L. N. (2011). Al 2 O 3-based nanofluids: a review. Nanoscale research letters, 6(1), 456.

[48]. Suresh, S., Chandrasekar, M., \& Sekhar, S. C. (2011). Experimental studies on heat transfer and friction factor characteristics of $\mathrm{CuO} /$ water nanofluid under turbulent flow in a helically dimpled tube. Experimental Thermal and Fluid Science, 35(3), 542-549.

[49]. Wakeham W.A., Nagashima A., Sengers J.V. (1991). Experimental Thermodynamics. Vol. III. Measurement of the transport properties of fluids, Oxford: Blackwell Scientific Publications. [A widespread book on experimental techniques for the measurement of transport properties].

[50]. Wen, D., \& Ding, Y. (2004). Experimental investigation into convective heat transfer of nanofluids at the entrance region under laminar flow conditions. International journal of heat and mass transfer, 47(24), 5181-5188.

[51]. Xue, Q. Z. (2003). Model for effective thermal conductivity of nanofluids. Physics letters A, 307(5-6), 313-317.

[52]. Zamzamian, A., Oskouie, S. N., Doosthoseini, A., Joneidi, A., \& Pazouki, M. (2011). Experimental investigation of forced convective heat transfer coefficient in nanofluids of $\mathrm{A} 12 \mathrm{O} / \mathrm{EG}$ and $\mathrm{CuO} / \mathrm{EG}$ in a double pipe and plate heat exchangers under turbulent flow. Experimental Thermal and Fluid Science, 35(3), 495-502. 
[53]. K.M. Shirvan, M. Mamourian, S. Mirzakhanlari, et al., Numerical investigation of heat exchanger effectiveness in a double pipe heat exchanger filled with nanofluid, A sensitivity analysis by response surface methodology, Powder Technol. 313 (2017) 99_ 111.

[54]. O. Keklikcioglu, V. Ozceyhan, Experimental investigation on heat transfer enhancement of a tube with coiled-wire inserts installed with a separation from the tube wall, Int. Commun. Heat Mass Tran. 78 (2016) 88-94.

[55]. X.T. Wang, N.B. Zheng, P. Liu, et al., Numerical investigation of shell side performance of a double shell side rod baffle heat exchanger, Int. J. Heat Mass Tran. 108 (2017) 2029-2039.

[56]. A.E. Maakoul, A. Laknizi, S. Saadeddine, Numerical comparison of shell-side performance for shell and tube heat exchangers with trefoil-hole, helical and segmental baffles, Appl. Therm. Eng. 109 (2016) 175-185.

[57]. A. Fouda, S.A. Nada, H.F. Elattar, H.A. Refaey, A. Bin Mahfouz, Thermal performance Modelling of turbulent flow in multi tubes in tube helically coiled heat exchangers, Int J Mech Sci 135 (2018) 621-638.

[58]. S.A. Nada, H.F. Elattar, A. Fouda, H.A. Refaey, Numerical investigation of heat $\underline{\text { transfer in annulus laminar flow of multi tubes-in-tube helical coil, Heat Mass Tran }}$ (2017), http://dx.doi.org/10.1007/s00231-017-2163-8.

[59]. Barzegar, M.H., Fallahiyekt M. (2018). Increasing the Thermal Efficiency of Double 445 Tube Heat Exchangers by Using Nano Hybrid. Emerging science Journal, 2, 1-10. 


\section{Figures}

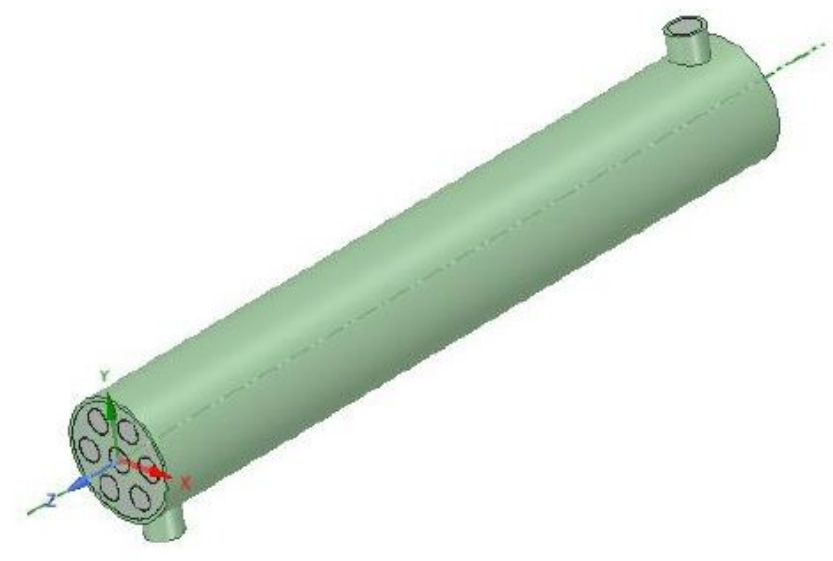

(a)

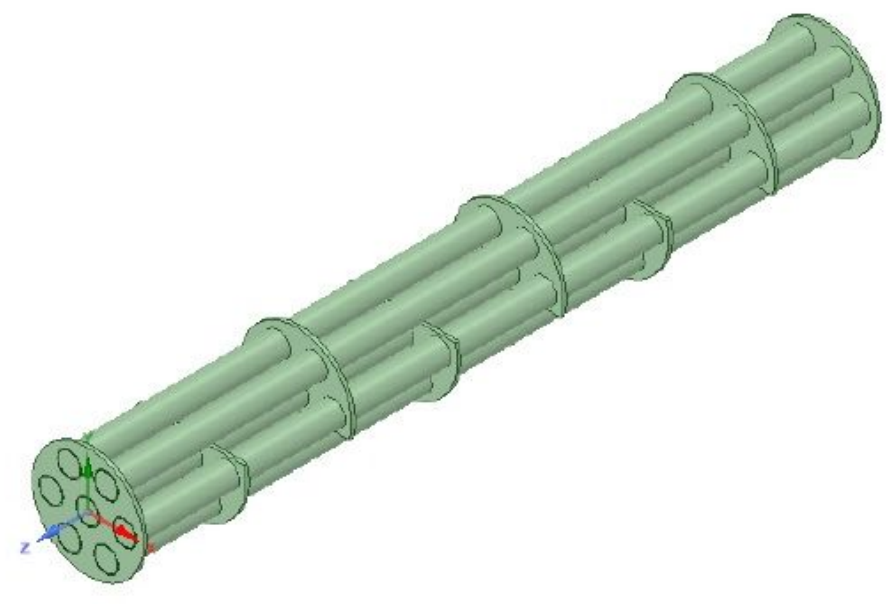

(b)

\section{Figure 1}

(a) STHX model (b) Tube bundle arrangement with baffles inside the shell.

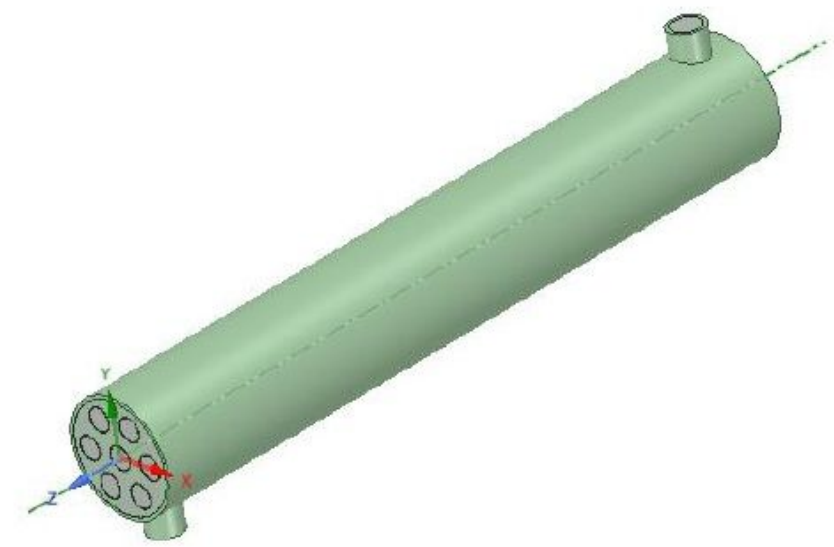

(a)

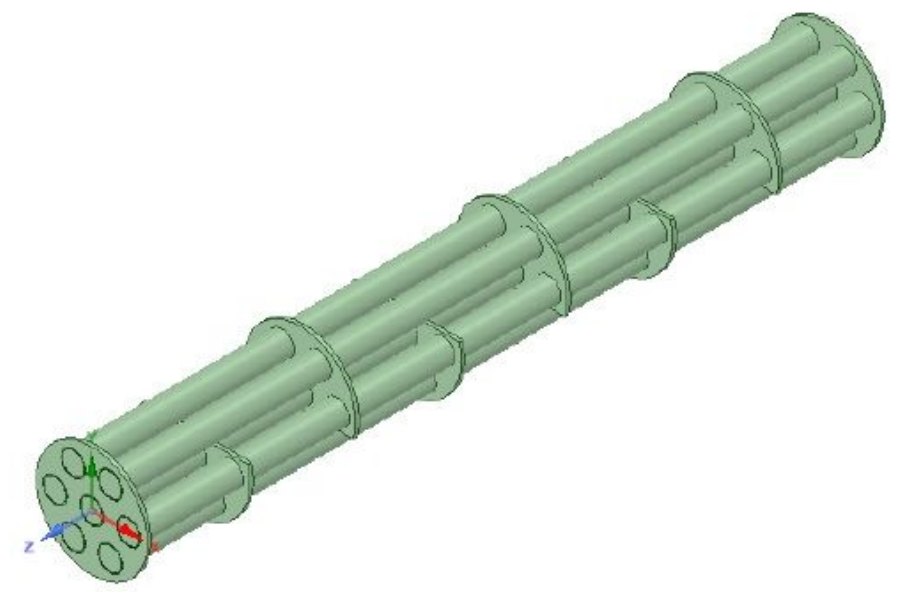

(b)

\section{Figure 1}

(a) STHX model (b) Tube bundle arrangement with baffles inside the shell. 

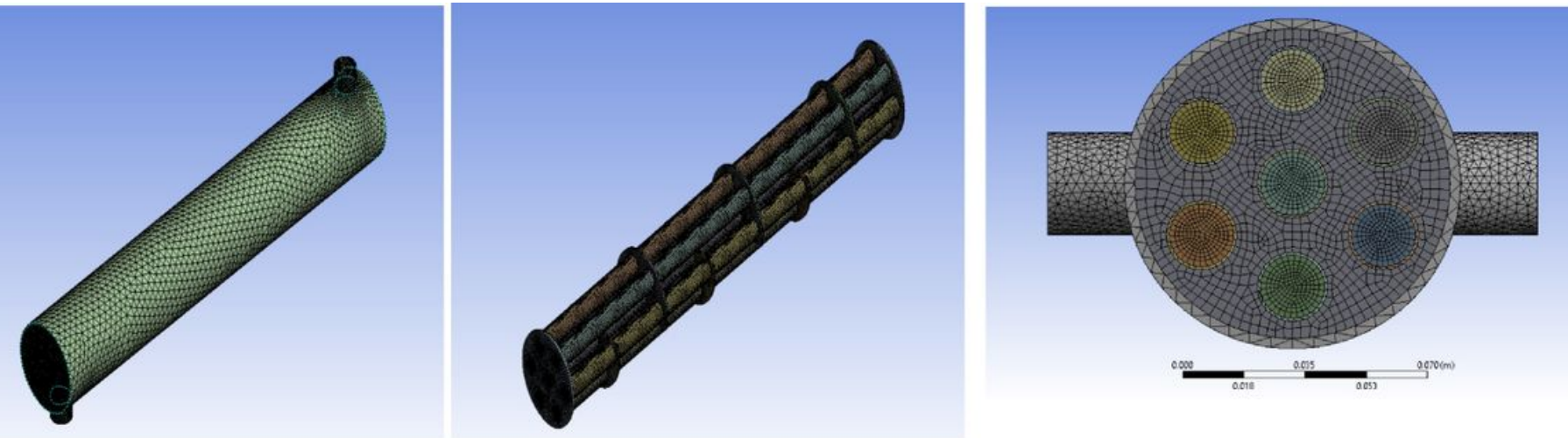

Figure 2

Meshed model.
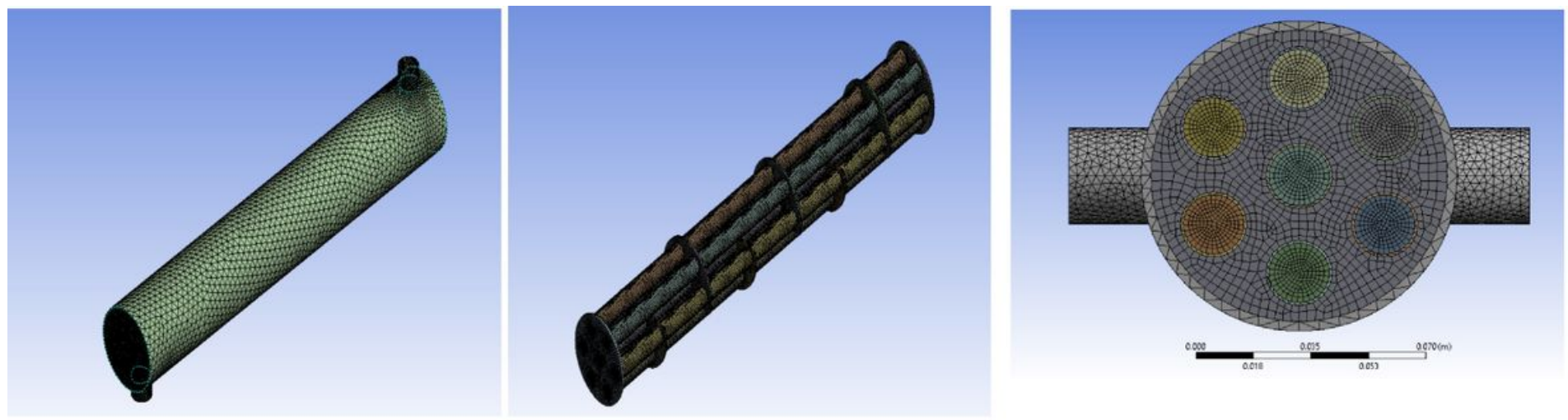

Figure 2

Meshed model. 


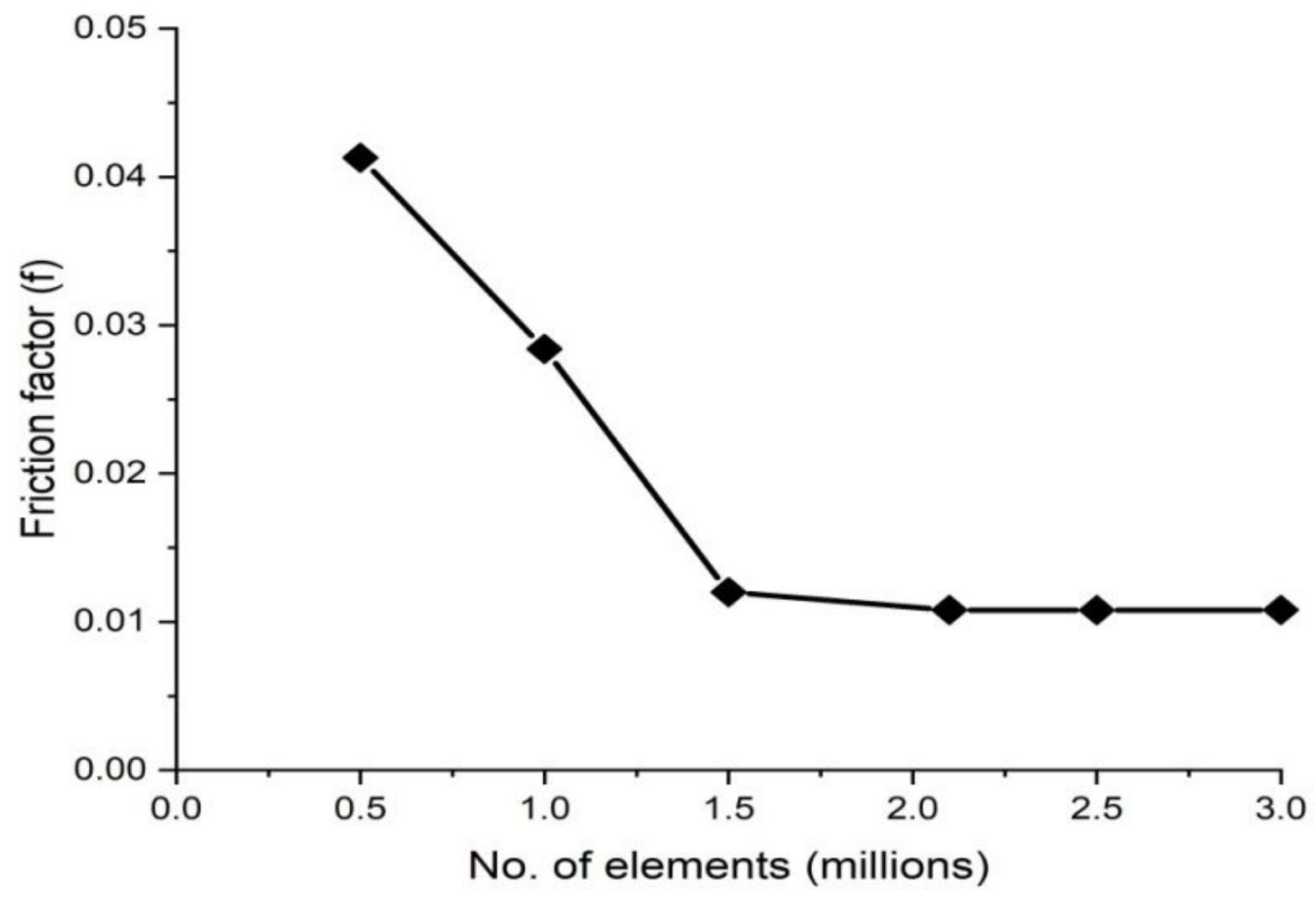

Figure 3

Grid independence study for turbulent regime. 


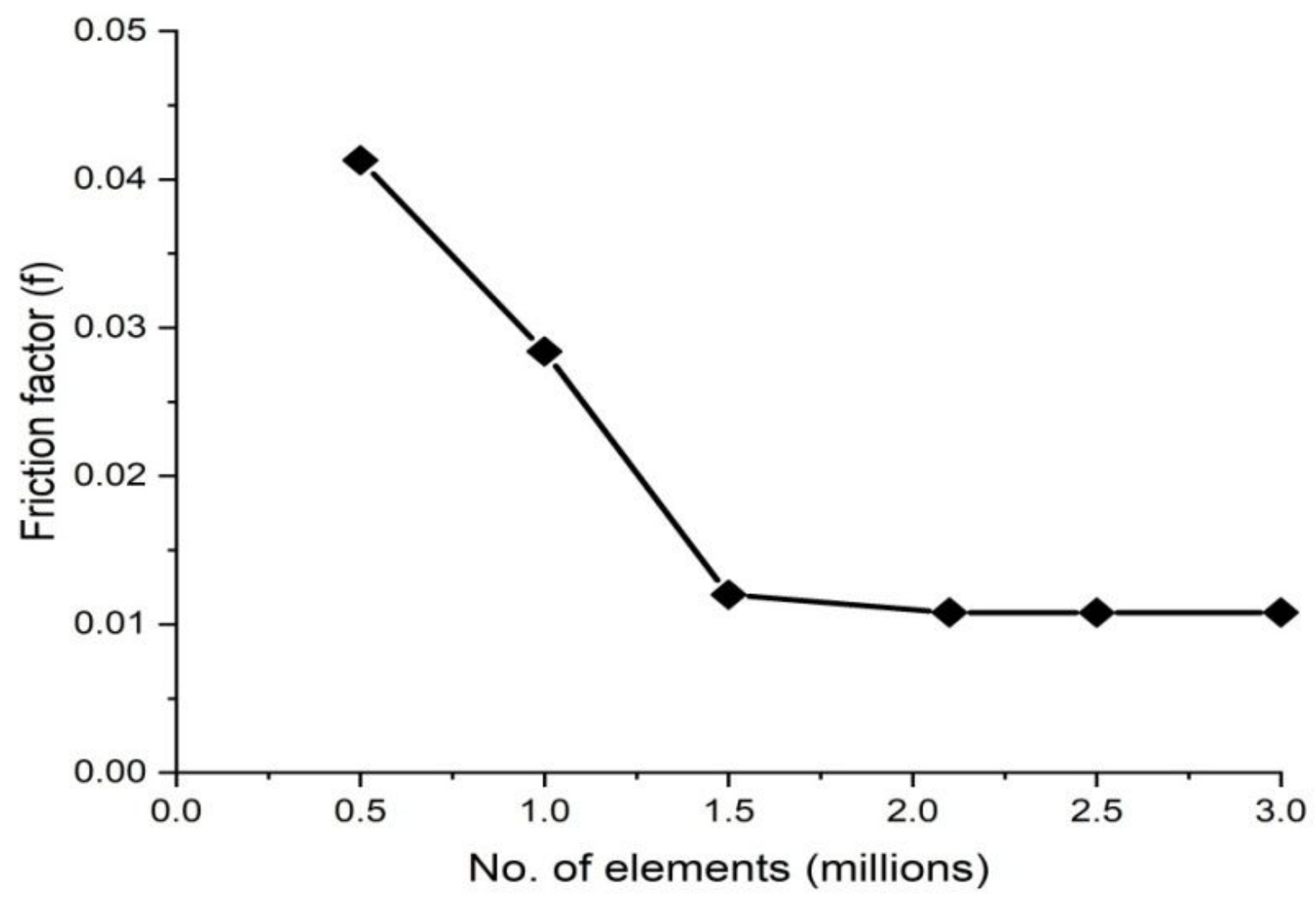

Figure 3

Grid independence study for turbulent regime.

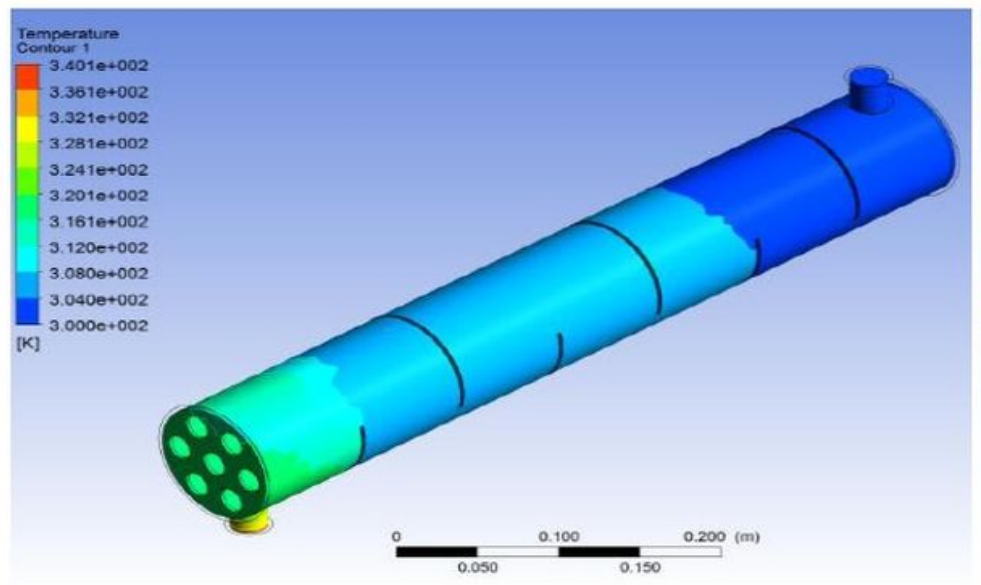

(a)

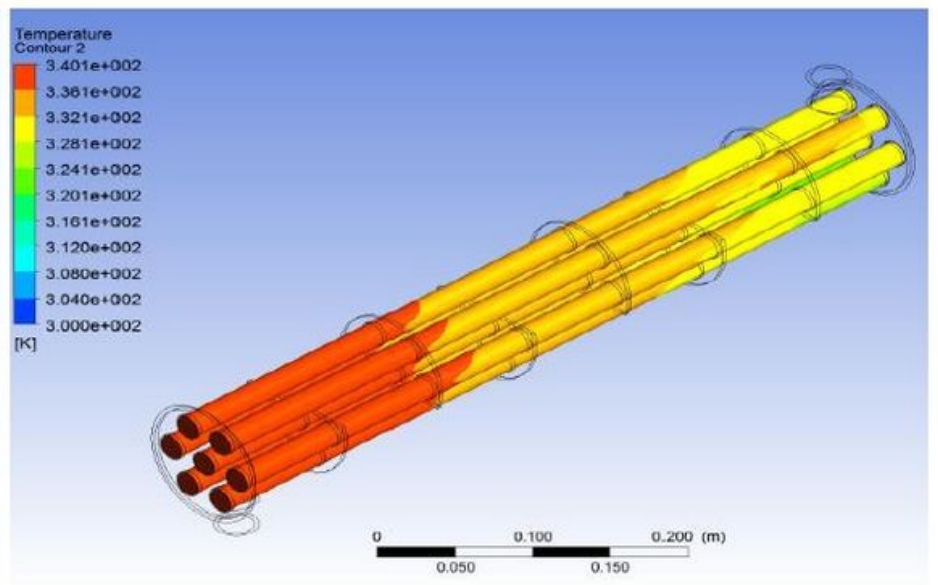

(b)

\section{Figure 4}

Temperature contours of (a) Cold fluid (b) Hot fluid through the tubes. 


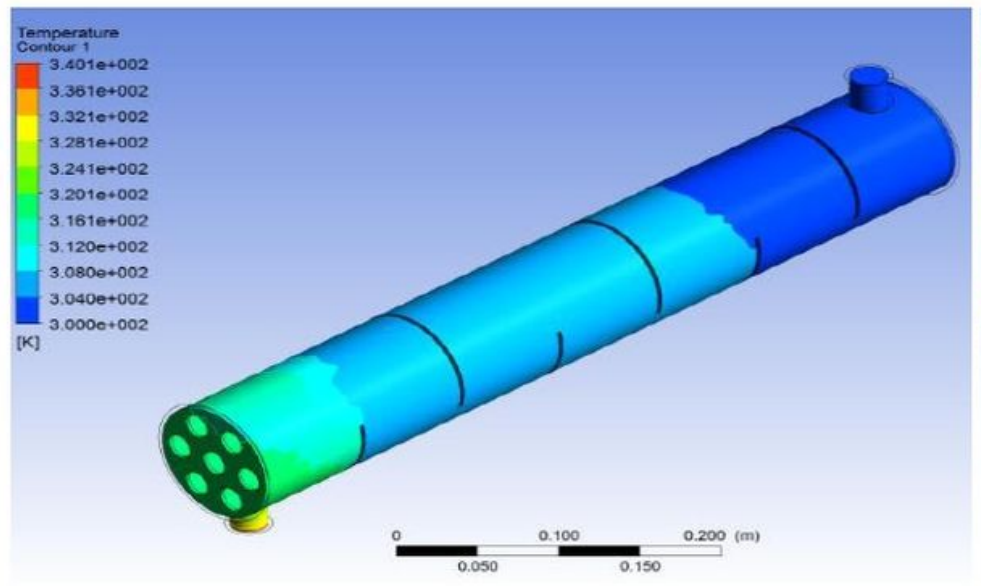

(a)

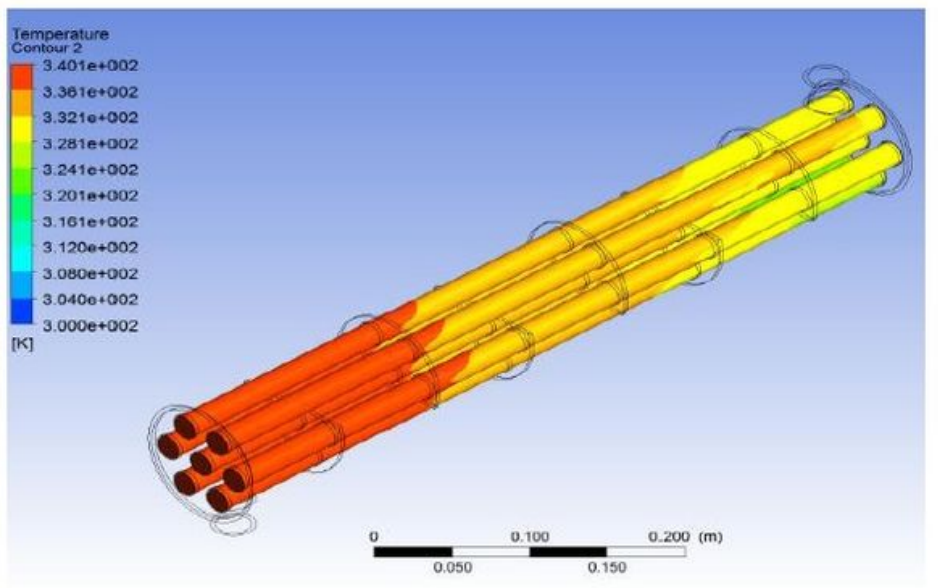

(b)

\section{Figure 4}

Temperature contours of (a) Cold fluid (b) Hot fluid through the tubes.

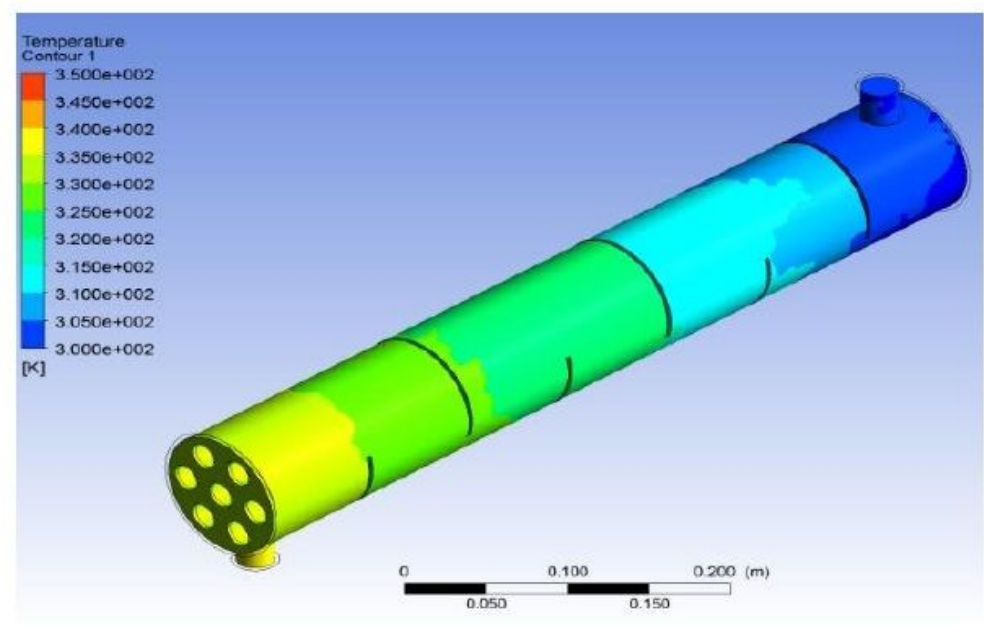

(a)

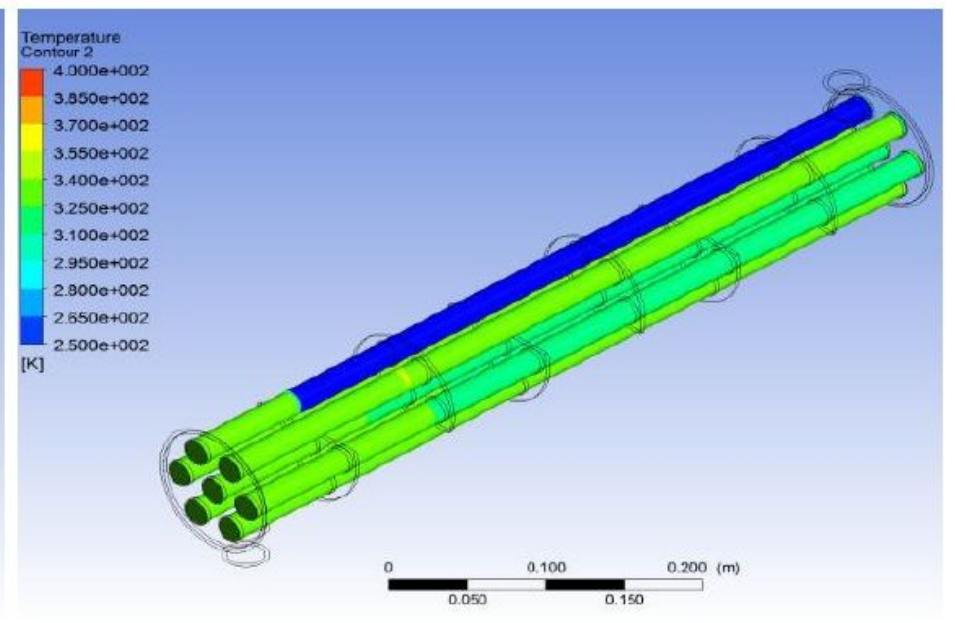

(b)

\section{Figure 5}

Temperature contours of (a) Nanofluid with 1\% Al2O3 (b) Hot fluid through the tubes. 


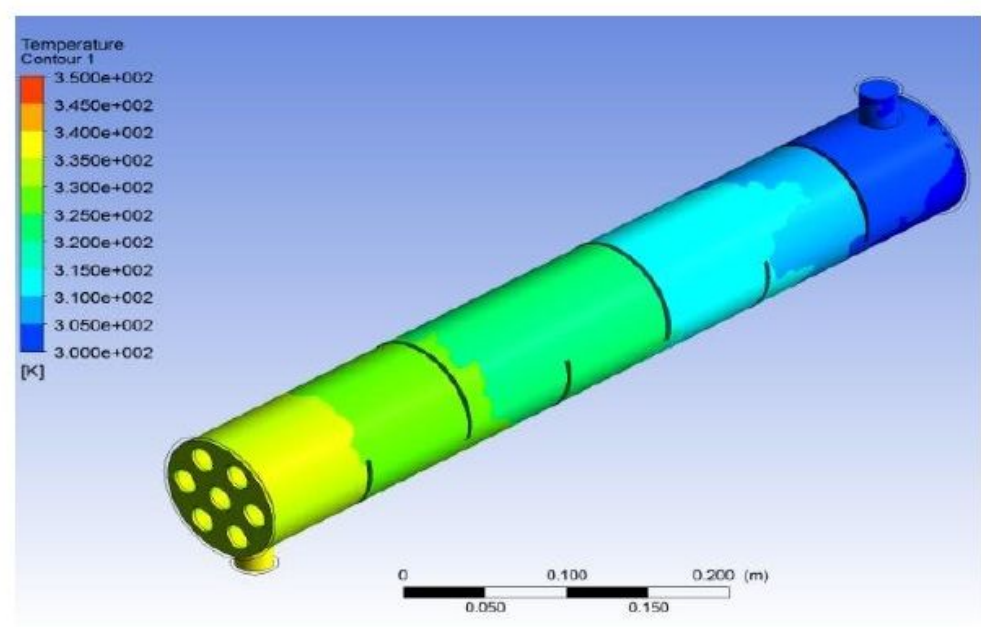

(a)

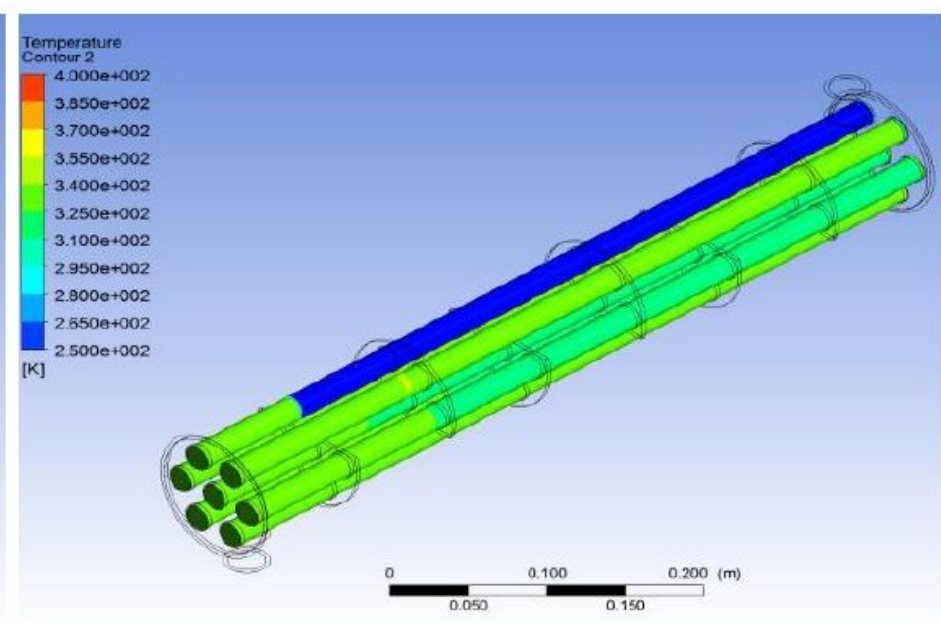

(b)

\section{Figure 5}

Temperature contours of (a) Nanofluid with 1\% Al2O3 (b) Hot fluid through the tubes. 